\title{
Remote Sensing Images to Detect Soy Plantations in the Amazon Biome-The Soy Moratorium Initiative
}

\author{
Bernardo F. T. Rudorff ${ }^{1, *}$, Marcos Adami ${ }^{1}$, Joel Risso ${ }^{1}$, Daniel Alves de Aguiar ${ }^{1}$, \\ Bernardo Pires ${ }^{2}$, Daniel Amaral ${ }^{2}$, Leandro Fabiani ${ }^{3}$ and Izabel Cecarelli ${ }^{3}$
}

1 National Institute for Space Research, Avenida dos Astronautas, 1758, São José dos Campos, SP, 12243-750, Brazil; E-Mails: adami@dsr.inpe.br (M.A.); risso@dsr.inpe.br (J.R.); daniel@dsr.inpe.br (D.A.A.)

2 Brazilian Association of Vegetable Oil Industries, Av. Vereador José Diniz, 3707, 7th floor, São Paulo, SP, 04603-004, Brazil; E-Mails: bernardo@abiove.org.br (B.P.); daniel@abiove.org.br (D.A.)

3 Geoambiente Consulting Engineering, Av. Shishima Hifumi, 2911, 2th floor, Parque Tecnológico UNIVAP, Urbanova, São José dos Campos, SP 12244-000, Brazil;

E-Mails: leandro.fabiani@geoambiente.com.br (L.F.); izabel.cecarelli@geoambiente.com.br (I.C.)

* Author to whom correspondence should be addressed; E-Mail: bernardo@dsr.inpe.br (B.R.); Tel.: +55-12-3208-6490; Fax: +55-12-3208-6488.

Received: 20 February 2012; in revised form: 15 May 2012 / Accepted: 16 May 2012 /

Published: 23 May 2012

\begin{abstract}
The Soy Moratorium is an initiative to reduce deforestation rates in the Amazon biome based on the hypothesis that soy is a deforestation driver. Soy planted in opened areas after July 24th, 2006 cannot be commercialized by the associated companies to the Brazilian Association of Vegetable Oil Industries (ABIOVE) and the National Association of Cereal Exporters (ANEC), which represent about 90\% of the Brazilian soy market. The objective of this work is to present the evaluation of the fourth year of monitoring new soy plantations within the Soy Moratorium context. With the use of satellite images from the MODIS sensor, together with aerial survey, it was possible to identify 147 polygons with new soy plantations on 11,698 ha. This soy area represents $0.39 \%$ of the of the total deforested area during the moratorium, in the three soy producing states of the Amazon biome, and $0.6 \%$ of the cultivated soy area in the Amazon biome, indicating that soy is currently a minor deforestation driver. The quantitative geospatial information provided by an effective monitoring approach is paramount to the implementation of a governance
\end{abstract}


process required to establish an equitable balance between environmental protection and agricultural production.

Keywords: Soy Moratorium; deforestation; Amazon forest; MODIS

\section{Introduction}

The process of colonizing the Brazilian Amazon started in the 1960s and was intensified in the following decades through the creation of public policies to stimulate occupation of the region with programs such as PIN (National Integration Program) and PROTERRA (Program for Land Redistribution and Stimulation of Agribusiness in the North and Northeast). PIN was created to protect the vast interior of Brazil by relocating citizens and to guarantee national sovereignty in the Amazon region, while PROTERRA supported these actions by creating better working conditions in the field and to foment agribusiness by providing the necessary infrastructure (roads, energy and its distribution, expansion of telecommunication networks etc.) to integrate the region into the domestic economy [1,2]. At the same time, the government offered tax incentives and credits for developing agriculture and livestock farming [3-5], and the lumber industry with consequent deforestation on a large scale [6]. With the start of an economic recession at the end of the 1980s and the beginning of the 1990s, the government reduced tax incentives which resulted in a decrease of the Amazon's deforestation annual rates from $\sim 20,400 \mathrm{~km}^{2}$ in the 1980s to $\sim 13,700 \mathrm{~km}^{2}$ between 1990 and 1994 . With the introduction of a new economic plan (Plano Real) in 1994 and the stabilization of the Brazilian economy, offers of credits with low interest rates increased and this, together with new government investments in infrastructure, led to an increase in deforestation, which reached $27,772 \mathrm{~km}^{2}$ in 2004 [3,5,7-10].

Several articles have dealt with the Amazon deforestation issue, showing its direct causal relationship with the expansion of agriculture and livestock farming, especially cattle farming [5,11-13] and soy production [14-19]. In this context, Greenpeace led a campaign for the conservation and reduction of deforestation in the Amazon biome, entitled "Eating up the Amazon" [20]. The scope of this campaign included publication of a report revealing that approximately one-quarter of the soy harvested in the Amazon was used to feed chickens that were later traded by the big fast-food chains.

Due to the repercussion of this evidence in the international scenario, several fronts, especially from the importer markets, pressured the productive soy chain sector to include in their agenda a commitment to preserve the forests. Consequently, in July 2006, Brazilian Vegetable Oil Industries Association (ABIOVE) and the National Grain Exporters Association (ANEC) announced the signing of the Soy Moratorium, an agreement that committed the member companies of ABIOVE and ANEC not to purchase soy produced in areas of the Amazon biome that were deforested after July $2006[21,22]$.

According to Lovatelli [22], soon after the declaration of the Soy Moratorium, in October 2006, the Soy Task Force (GTS) was formed, consisting of representatives from the soy productive chain sector (ABIOVE, ADM, ANEC, Algar Agro, Amaggi, Baldo, Bunge, Cargill, IMCOPA, Louis Dreyfus and Óleos Menu) and from the civil society (Greenpeace, International Conservation, IPAM, 
The Nature Conservancy and WWF-Brasil). The GTS mission was to plan and coordinate the Soy Moratorium's activities. In addition to the Coordination Group, the Soy Moratorium also had the following three subgroups:

i) EDUCATION, INFORMATION and FOREST CODE: This subgroup disseminates the adoption of good soy production practices in the Amazon biome to ensure that the actions generated by the Soy Moratorium reach the rural producers and the other economic, social and political agents involved, mainly those with local relevance, and contributes to agribusiness, keeping the proper balance between economic and social-environmental needs, thus ensuring compliance with legislation;

ii) INSTITUTIONAL RELATIONS: This subgroup brings the GTS closer to the members of government entities, with a view to improving sustainable development policies for the Amazon biome and to stimulating legislative advancements to improve the region's command and control mechanisms;

iii) MAPPING and MONITORING: This subgroup supports the development of a system to map and monitor the Amazon biome, defining the methods and the criteria necessary to assure compliance with the commitment not to trade soy originating from deforested areas.

Over the last few years, Brazilian institutions such as the Ministry of the Environment, Bank of Brazil and National Institute for Space Research (INPE) began to collaborate with the Soy Moratorium. Starting in 2009, INPE assumed the responsibility for developing and applying a methodology for monitoring soy plantations in deforested areas of the Amazon biome through the use of satellite images.

It also is important to mention that since the early 2000s the Brazilian government has implemented a comprehensive set of measures to fight illegal deforestation, highlighting the PPCDAM (Action Plan for the Prevention and Control of Deforestation in the Legal Amazon) implemented in 2003 [23]. Other important public policies include the Ecologic-Economic Zoning (ZEE) established by the states, a listing of degrading working conditions kept by the Ministry of Labor, a listing of embargoed areas kept by the Ministry of the Environment, reinforcement of supervision by environmental entities and a big advance in real-time monitoring of deforestation and forest fires using satellite images. With the use and expansion of these new tools, the improvement in public governance over the last five years has been very significant.

In this panorama, the objective of this work is to present the evaluation of the fourth year of monitoring new soy plantations within the Soy Moratorium context.

\section{Material and Methods}

The sections of material and methods presented in this study are summarized in the flowchart presented in Figure 1. 
Figure 1. Flowchart of the summary of material and methods.

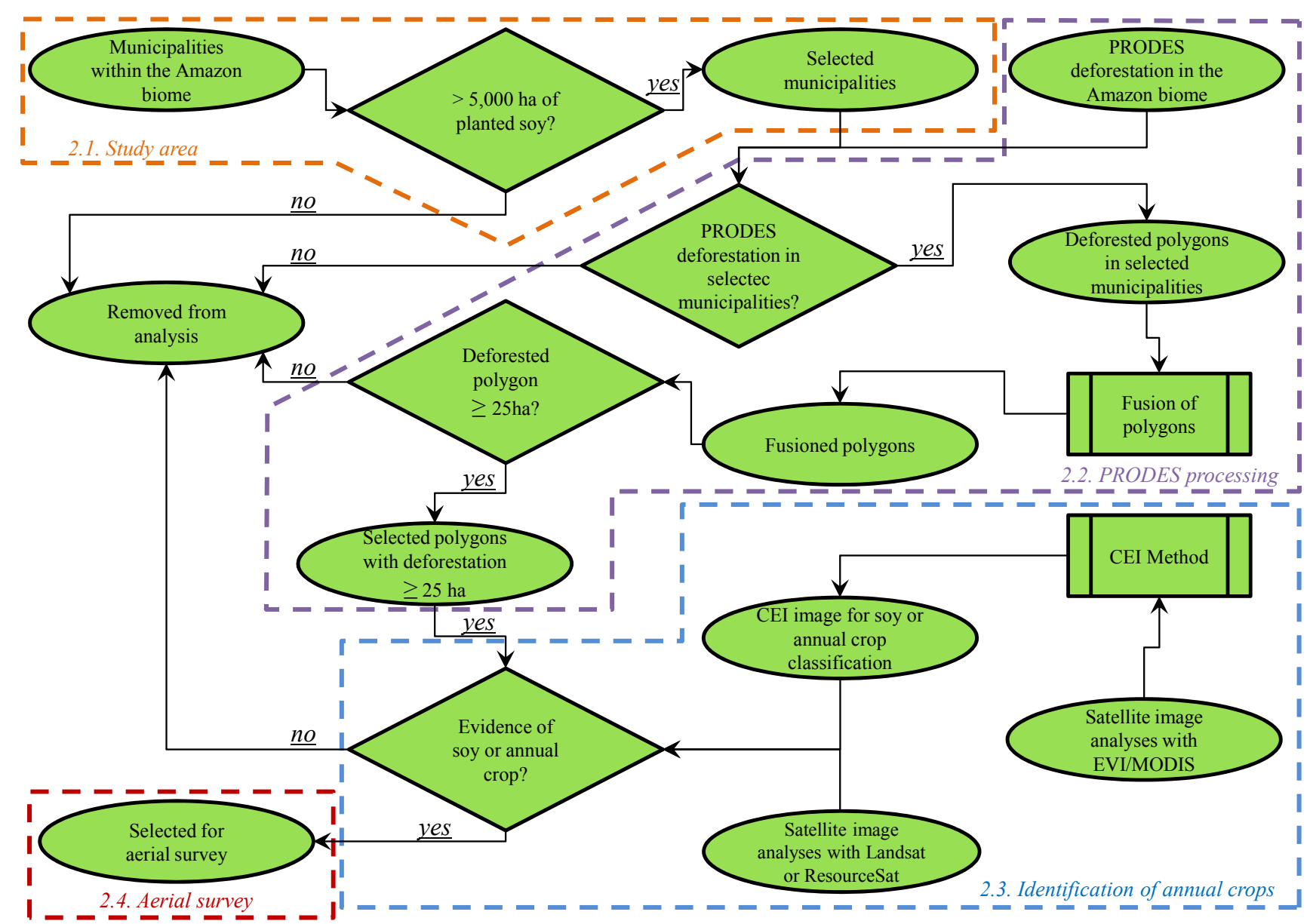

\subsection{Study Area}

The study area is the Amazon biome, which covers nine states with 553 municipalities and an area of 4.2 million $\mathrm{km}^{2}$, representing approximately half of Brazil's territory. This biome is made up of the world's largest tropical rain forest, with a very significant biodiversity and quantity of carbon accumulated in the form of biomass. According to Soares-Filho et al. [24], the quantity of carbon stored in the Amazon in the form of biomass is equivalent to 15 years of anthropic emissions of carbon dioxide $\left(\mathrm{CO}_{2}\right)$ at current emission levels.

Currently, 7.5\% of Brazil's soy area is in the Amazon biome and concentrated in the states of Mato Grosso (MT), Rondônia (RO) and Pará (PA), which comprise 99\% of this area [25]. Together these states are responsible for $78.7 \%$ of the deforestation mapped by the Amazon Deforestation Monitoring Project (PRODES) since the beginning of the Soy Moratorium [7]. Therefore, deforested polygons mapped by PRODES were monitored to detect soy plantations in municipalities of these three states with a minimum soy area of 5,000 hectares (ha) each, according to the survey of the previous crop year made by the Brazilian Geographic and Statistical Institute (IBGE). In this way, for the year 2011, 53 municipalities (41 in MT, 6 in RO and 6 in PA) were selected, representing $98 \%$ of the soy area in the Amazon biome (Figure 2). 
Figure 2. (a) The Brazilian Amazon biome (yellow line); (b) The 53 municipalities (red line) with more than 5,000 ha of soy each that represent $98 \%$ of the soy area in the Brazilian Amazon biome.

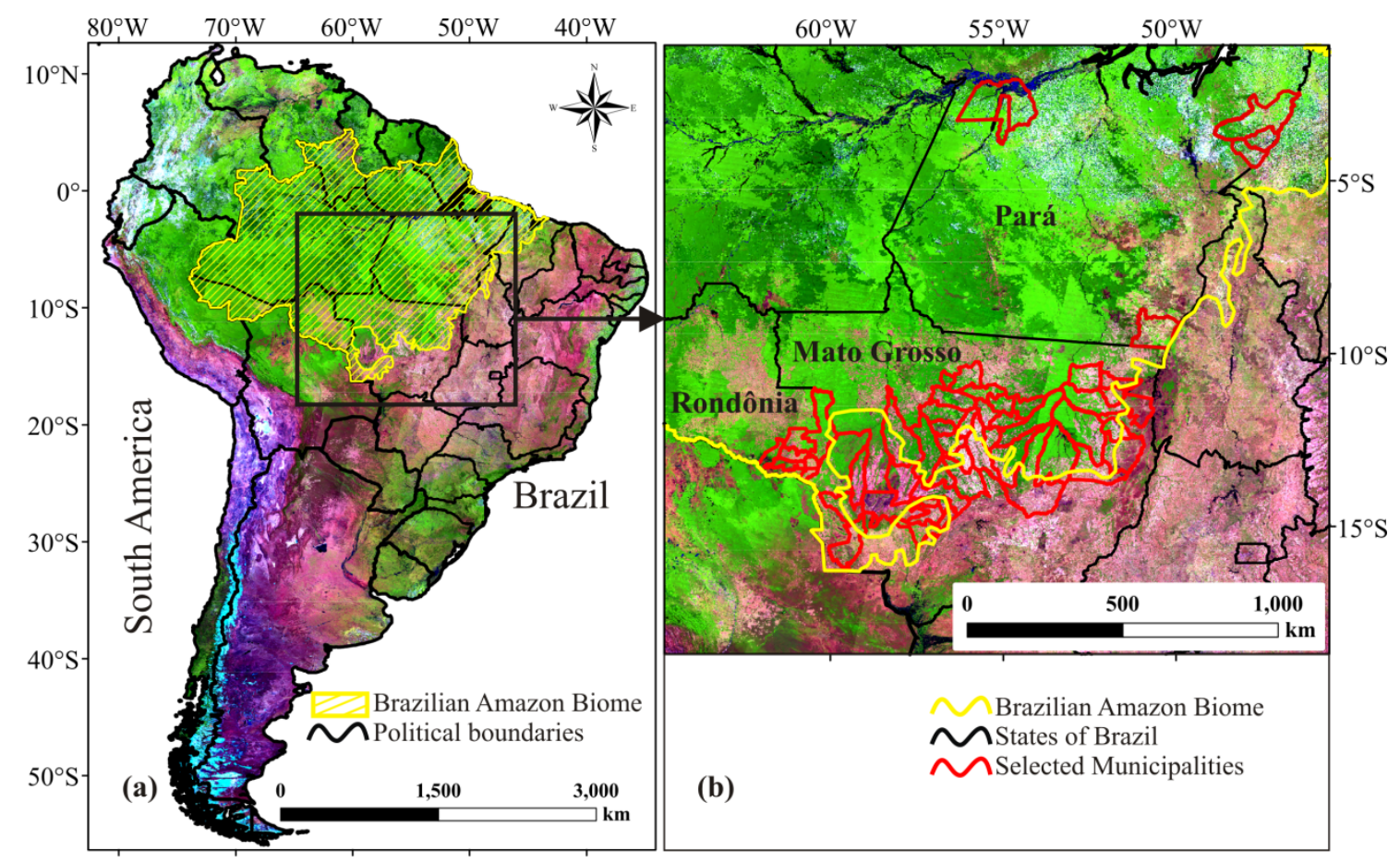

\subsection{Preprocessing of Deforested Polygons from the PRODES Project}

The Amazon Deforestation Monitoring Project (PRODES), developed and carried out by INPE, identifies on an annual basis the deforested areas in the Amazon region. The international scientific community considers PRODES to be the world's major tropical forest monitoring program [26]. Since 1988, INPE has monitored, mapped and estimated the annual deforestation rate for the entire Brazilian Legal Amazon region. Starting in 2002, the analogical deforestation mapping procedure was converted to a digital system in which Landsat images are automatically classified and later edited through visual interpretation on the computer screen. Deforestation maps are inserted into a georeferenced database and made available on the internet (http://www.obt.inpe.br/prodes/) [7,27,28]. Table 1 shows the data supplied by PRODES for MT, RO and PA states, related to deforested polygons mapped in the Amazon biome during the Soy Moratorium.

Table 1. Total annual deforested area (ha) in MT, RO and PA states during the Soy Moratorium.

\begin{tabular}{cccccc}
\hline \multirow{2}{*}{ State } & \multicolumn{5}{c}{ Year of evaluation * } \\
\cline { 2 - 6 } & $\mathbf{2 0 0 7}$ & $\mathbf{2 0 0 8}$ & $\mathbf{2 0 0 9}$ & $\mathbf{2 0 1 0}$ & Total \\
\hline MT & 237,142 & 317,123 & 68,438 & 65,757 & 688,460 \\
RO & 161,100 & 113,600 & 48,200 & 43,500 & 366,400 \\
PA & 552,600 & 560,700 & 428,100 & 377,000 & $1,918,400$ \\
Total & 950,842 & 991,423 & 544,738 & 486,257 & $2,973,260$ \\
\hline
\end{tabular}

* The PRODES mapping year refers to the period from August of the previous year to July of the current year. For example, deforestation of 2007 refers to the deforestation observed from August 2006 to July 2007. Source: Adapted from [7]. 
All deforested polygons from the period between 2007 and 2010, related to MT, RO and PA states, were selected from the PRODES database. These polygons were then intersected with the boundaries of both the 53 municipalities with more than 5,000 ha each and the Amazon biome, to select only those deforested polygons located within the Amazon biome, and the selected municipalities.

The GTS agreed to monitor only deforested polygons $\geq 25$ ha due to the moderate spatial resolution $(250 \mathrm{~m})$ of the satellite images from the MODIS (Moderate Resolution Imaging Spectroradiometer) sensor [29-31] used to identify soy crop within these polygons. However, smaller areas of deforestation that begin in specific spots are very often not isolated events that occur in a single year, but gradually increase through deforestation of adjacent areas in following years, thus forming larger deforested areas $[4,21,32]$. Therefore, annual deforested polygons of $<25$ ha were also monitored when the sum of the annual and adjacent deforested polygons became $\geq 25$ ha. For this reason, adjacent deforested polygons with $<25$ ha were aggregated to form polygons $\geq 25$ ha, according to the methodology described by [21].

\subsection{Identification of Soy Crop Within Deforested Polygons Using Satellite Images}

Due to intense cloud cover in the Amazon region [33,34] the identification of soy plantations using optical remote sensing images is not feasible with the current temporal resolution of Landsat type images (16 days). Part of this difficulty can be solved with the use of images from high temporal resolution sensors, thus increasing the probability of obtaining cloud-free images. In this sense, the MODIS sensor is an alternative as it has an almost daily temporal resolution, as well as geometric [35] and radiometric [36] qualities that produce images in 36 spectral bands, with products generated by means of tested algorithms and the generation of validated products [37]. Allying the geometric quality of the images, which allows the composition of time series and guaranteed pixel geolocation with the attributes of radiometric and spectral quality of validated products, one can ensure that the MODIS data is of good quality [35,38,39].

Although MODIS images have frequently been used to classify soy with relatively good accuracy figures, particularly in the state of MT [40,41], these results are not accurate enough for the purpose of the Soy Moratorium due to some classification confusion with other annual crops, such as rice and corn. For classification of annual crops with MODIS images, an overall accuracy of $88.5 \%$ was achieved by Galford et al. [42]. From previous Soy Moratorium work, it was observed that more than $90 \%$ of the deforested polygons did not present any annual crop and, consequently, less than $10 \%$ of the deforested polygons needed to be aerially surveyed to ensure the correct detection of soy plantations among the polygons with potential presence of annual crops [21]. Therefore, the MODIS images play a crucial role just by detecting annual crops, eliminating more than $90 \%$ of the polygons in which soy plantation is very unlikely to be found. According to the results from the Terra Class Project [43], more than $90 \%$ of the original tropical rain forest in the Legal Amazon mapped by PRODES from 1988 to 2007 is now occupied by pasture, secondary forest or regenerated forest, and only $4.6 \%$ is occupied by annual crops.

Deforested polygons with signs of presence of soy plantation or any other annual crop with similar seasonality to soy were selected based on the Crop Enhancement Index (CEI) method, proposed by [44], as presented by [21]. The CEI is an approach to detect the seasonality of annual crop based on the 
significant difference between the Enhanced Vegetation Index (EVI) [45] values, derived from MODIS images, acquired at two specific periods: 1) prior to the beginning of the crop growing season when EVI values are at a minimum for annual crops; and 2) at mid growing season when EVI values are at maximum for annual crops [46,47] (Figure 3). The typical seasonality observed for annual crops allow them to be differentiated from other targets such as regenerated forest, savanna or pasturing (Figure 3).

Figure 3. Example of typical temporal profiles of EVI values for early and late sowing soy according to crop calendar in MT state, regenerated forest, savanna/pasture and forest.

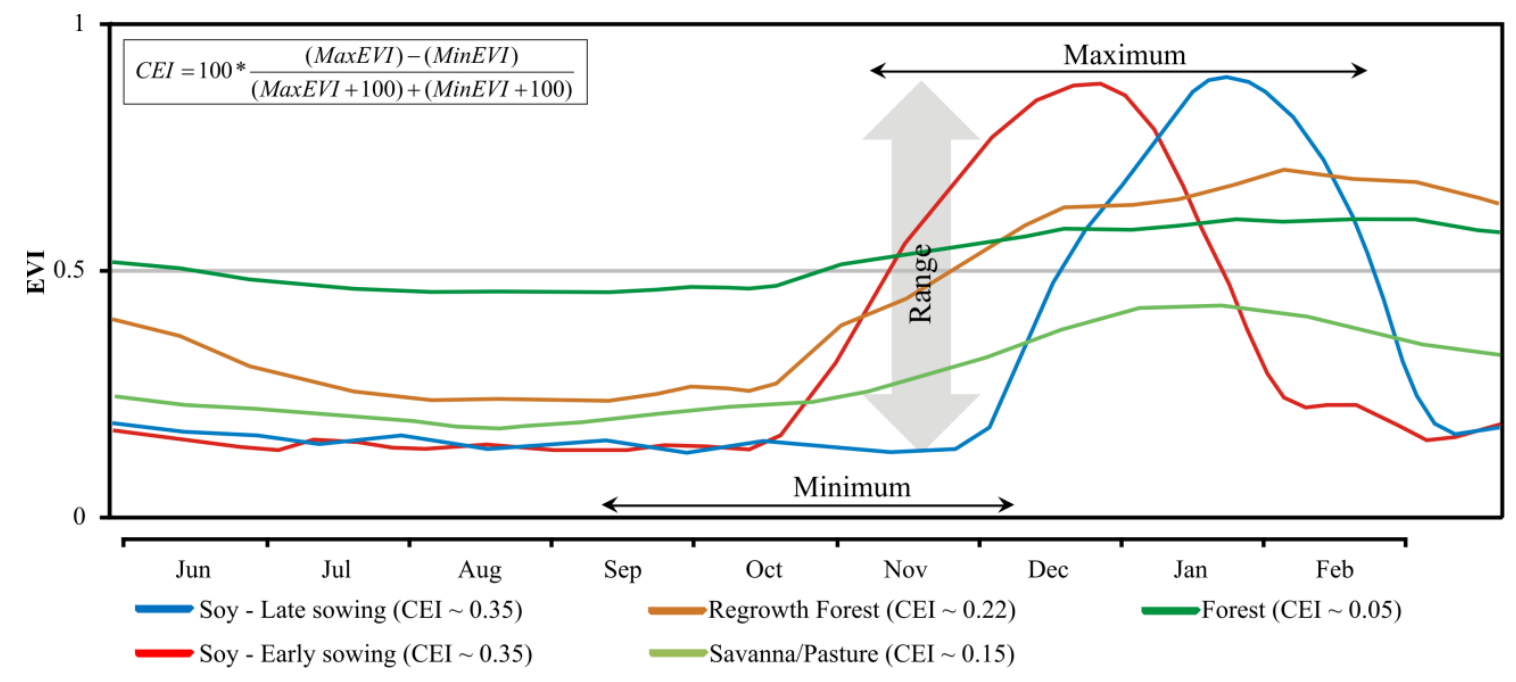

For the Soy Moratorium, the CEI method was adapted and the maximum EVI value used in the CEI equation (Figure 3) was acquired during the crop greenup phase, right after the EVI values established significant variation between minimum and maximum values, particularly to detect late sowing soy (Figure 3). The relative early crop detection in the growing season is important to allow enough time for the aerial survey and field work that have to be accomplished prior to the soy harvest in late January for the early sowing soy. Furthermore, early and late sowing soy are planted in the same region and both should be detected in a single aerial survey to avoid cost increase. From the experience acquired in the previous crop year (2009/2010), it became evident that the soy planting period was similar in MT and RO states, but rather different in PA state. According to the soy calendar in MT and RO the maximum EVI values were obtained based on MODIS images (MOD09 product, 8-day composition) acquired from early December, 2010 to early January, 2011. For the crop calendar of PA state the maximum EVI values were obtained based on MODIS images acquired from early February to early March, 2011. Any significant seasonal change captured by the CEI approach was enough to classify a polygon as annual crop. This strategy increases the commission error, but reduces the possibility of not classifying a less evident soy plantation, lowering the omission error. To refine the MODIS classification procedure, the polygons classified as annual crops were submitted to a visual interpretation whenever recent cloud-free images acquired by either Landsat (TM or ETM+ sensors) or Resourcesat-1 (AWIFS or LISS3 sensors) were available at the website of INPE's Division of Image Generation [48]. In general, only very few cloud-free images from these sensors are available during the soy growing season, but the 2010/2011 crop season was particularly favorable in this respect. 


\subsection{Aerial Survey to Identify Soy Plantation among Annual Crops}

The deforested polygons classified by the satellite images as annual crops were subjected to aerial survey to accurately identify those with soy plantation. The airplane was equipped with GPS and photographic equipment to obtain panoramic photographs from about $400 \mathrm{~m}$ above ground. These photos were visually analyzed to identify not only soy crop but also other land uses, such as rice, corn, pasture and natural regeneration. To complete this work, 157 hours of aerial survey were carried out between late January, 2011 and late April, 2011, flying a total of 20,400 km over 29 municipalities in which deforested polygons with annual crops were present.

\section{Results and Discussion}

The number of deforested polygons and its area (ha) mapped by PRODES since the beginning of the Soy Moratorium, for the 53 selected municipalities with more than 5,000 ha each, before and after the aggregation of adjacent deforested polygons are shown in Table 2. These results are presented for the deforested polygons $<25$ ha and $\geq 25$ ha. After aggregation, the deforested polygons with $<25$ ha decreased in number and, consequently, in area (54,544 ha; $-33 \%$ ); while the total area of deforested polygons with $\geq 25$ ha increased $16.9 \%$ after aggregation (Table 2), agreeing with [4,32]. Table 2 further shows that the total deforested area, before and after aggregation, is practically the same, corresponding to about 486,000 ha. Of this total, 375,500 ha were effectively monitored comprising 3,571 deforested polygons of $\geq 25$ ha. In other words, $77.3 \%$ of the deforested area was monitored, and the remaining $22.7 \%$ that was not monitored corresponds to the isolated deforested polygons of $<25$ ha.

Table 2. Number of deforested polygons and corresponding area (ha) before and after aggregation by class of deforestation size ( $<25$ ha and $\geq 25$ ha) for the 53 municipalities with more than 5,000 ha each.

\begin{tabular}{ccccccc}
\hline \multirow{2}{*}{$\begin{array}{c}\text { Class of } \\
\text { Deforestation Size }\end{array}$} & \multicolumn{2}{c}{ Before Aggregation (a) } & \multicolumn{2}{c}{ After Aggregation (b) } & \multicolumn{2}{c}{ Variation $\{(\mathbf{b}-\mathbf{a}) / \mathbf{a}\}$} \\
\cline { 2 - 7 } & $\mathbf{N}^{\circ}$ & Area (ha) & $\mathbf{N}^{\circ}$ & Area (ha) & $\mathbf{N}^{\circ}$ & Area (ha) \\
\hline$<25$ ha & 12,579 & 165,156 & 8,470 & 110,612 & $-32.7 \%$ & $-33.0 \%$ \\
$\geq 25$ ha & 3,618 & 321,079 & 3,571 & 375,500 & $-1.3 \%$ & $16.9 \%$ \\
Total & 16,197 & 486,235 & 12,041 & 486,112 & $-25.7 \%$ & $0.0 \%$ \\
\hline
\end{tabular}

The 3,571 deforested polygons with $\geq 25$ ha were analyzed one by one, based on MODIS images and available Landsat and/or Resourcesat-1 images. Of this total, 3,236 polygons, corresponding to $90.6 \%$ of the number of deforested polygons, did not show any signs of soy or annual crop. In the remaining 335 deforested polygons the satellite images indicated the possible presence of soy or any other annual crop (Table 3). Forty-two of these deforested polygons were located in settlements and were therefore not monitored according to what was agreed by the GTS to not penalize agrarian reform settlers, based on the principle that economic development and social inclusion should walk hand-in-hand with environmental conservation. Eventually, 293 deforested polygons (8.2\%) were selected for aerial survey. It should be pointed out that no deforested area with annual crops was found inside Indigenous Lands or Conservation Units. 
Table 3. Number of deforested polygons with and without annual crops by state.

\begin{tabular}{lcccc}
\hline \multirow{2}{*}{ Deforested polygons } & \multicolumn{3}{c}{ States } \\
\cline { 2 - 5 } & MT & PA & RO & Total (\%) \\
\hline Without annual crops & 1,929 & 1,133 & 174 & $3,236(90.6 \%)$ \\
With annual crops & 214 & 78 & 1 & $293(8.2 \%)$ \\
With annual crops-within settlements * & 42 & 0 & 0 & $42(1.2 \%)$ \\
Total & 2,185 & 1,211 & 175 & $3,571(100 \%)$ \\
\hline
\end{tabular}

* Not monitored.

From the aerial survey of the 293 deforested polygons, soy plantations were found in 146 polygons, with a total area of 11,698 ha (Table 4). This indicates that the conversion of forest to soy in the Amazon biome during the Soy Moratorium corresponds to: $0.3 \%$ of total deforestation; $0.39 \%$ of the deforestation in the states of $\mathrm{MT}, \mathrm{RO}$ and $\mathrm{PA} ; 2.4 \%$ of the deforestation observed in the 53 municipalities that produce more than 5,000 ha of soy each; or $3.1 \%$ of the deforestation observed in polygons $\geq 25$ ha in these same municipalities.

Table 4. Number of deforested polygons and corresponding soy area (ha) by classes of deforestation size.

\begin{tabular}{ccccccccc}
\hline $\begin{array}{c}\text { Class of } \\
\text { Deforestation size }\end{array}$ & \multicolumn{2}{c}{ MT } & \multicolumn{2}{c}{ PA } & \multicolumn{2}{c}{ RO } & \multicolumn{2}{c}{ Total } \\
\hline (ha) & $\mathrm{N}^{\circ}$ & $(\mathrm{ha})$ & $\mathrm{N}^{\circ}$ & (ha) & $\mathrm{N}^{\circ}$ & (ha) & $\mathrm{N}^{\circ}$ & (ha) \\
\hline $25-50$ & 40 & 1,149 & 17 & 418 & 1 & 29 & 58 & 1,567 \\
$50-100$ & 23 & 1,340 & 10 & 445 & - & - & 33 & 1,785 \\
$>100$ & 42 & 5,896 & 13 & 2,421 & - & - & 55 & 8,346 \\
Total & 105 & 8,385 & 40 & 3,284 & 1 & 29 & 146 & 11,698 \\
\hline
\end{tabular}

In MT state, 105 deforested polygons were identified as not meeting the Soy Moratorium's requirements, representing 8,385 ha of soy (Table 4 ). This corresponds to $1.2 \%$ of the total deforested area in MT state $(688,460$ ha; Table 1) during the Soy Moratorium. In PA state, 40 deforested polygons were identified as having soy, representing 3,284 ha (Table 4). This corresponds to $0.17 \%$ of the deforested area in PA state $(1,918,400$ ha; Table 1) during the Soy Moratorium. Only one deforested area with soy was identified in RO state, representing 29 ha (Table 4) of a total deforested area of 366,400 ha in RO (Table 1). It should be emphasized that, of the 293 selected polygons for aerial survey (Table 2), 113 were from deforested polygons with more than 100 ha, of which 55 were identified as having soy. The soy area of these polygons was 8,346 ha (Table 4), which corresponds to $71 \%$ of the total soy planted in deforested polygons, thus indicating that the great majority of soy plantations occurred in deforested polygons with more than 100 ha. Further details on the selected polygons can be found at [49].

Table 5 shows that from crop year 2009/10 to 2010/11, the monitored area increased by $24 \%$ (from 302,149 ha to $375,500 \mathrm{ha}$ ), but the soy area increased by $86 \%$ (from 6,295 ha to $11,698 \mathrm{ha}$ ). An important factor to be considered in this 4th year of the Soy Moratorium is the longer time that had elapsed since its beginning, due to the fact that rice crops often precede soy crops during the first two years after deforestation [16,50]. Under this consideration the intention of planting soy in 
deforestations of the first two years (2007 and 2008) should appear in the 4th year. Therefore, the increase of 5,403 ha of soy ( $86 \%$; Table 5), compared to the sum of the deforestations observed in 2007 and $2008(1,942,265$ ha; Table 1$)$, is minor.

Table 5. Comparison between crop years 2009/10 and 2010/11 of deforested polygons and those with new soy in the 53 analyzed municipalities.

\begin{tabular}{lccc}
\hline & $\mathbf{2 0 0 9 / 1 0}(\mathbf{a})$ & $\mathbf{2 0 1 0 / 1 1}(\mathbf{b})$ & Variation $\{(\mathbf{b}-\mathbf{a}) / \mathbf{a}\} \mathbf{( \% )}$ \\
\hline Total area of deforested polygons (ha) & 302,149 & 375,500 & 24 \\
Total no. of deforested polygons & 2,955 & 3,571 & 21 \\
No. of deforested polygons with soy & 76 & 146 & 92 \\
New soy area in deforested polygons (ha) & 6,295 & 11,698 & 86 \\
\hline
\end{tabular}

The results of crop year 2010/11 show that soy was planted in $0.39 \%$ of the total deforested area observed in the three soy producing states of the Amazon biome, since the inception of the Soy Moratorium. Considering the soy area planted in the Amazon biome (1.94 million ha), the amount of soy in deforested polygons observed during the Soy Moratorium represents $0.6 \%$ (Table 6). In view of the results, there are strong indications that the Soy Moratorium has, for the last four years, inhibited the advance of deforestation for the purpose of planting soy in the Amazon biome. It should be pointed out that, in MT state, which is responsible for $88 \%$ of the Amazon biome's soy area, the soy planted in deforested polygons during the Soy Moratorium represent just $0.49 \%$ of the state's soy area within the Amazon biome (Table 6).

Table 6. Soy area (ha) in deforested polygons and in the Amazon biome; and relative contribution of new soy in deforested polygons.

\begin{tabular}{cccc}
\hline State & New soy in deforested polygons (b) & Soy in Amazon biome (a)* & $(\mathbf{a * 1 0 0 / b ) ~ ( \% )}$ \\
\hline MT & 8,385 & $1,704,963$ & $0.49 \%$ \\
PA & 3,284 & 104,800 & $3.13 \%$ \\
RO & 29 & 132,300 & $0.02 \%$ \\
Total & 11,698 & $1,942,063$ & $0.60 \%$ \\
\hline
\end{tabular}

Source: * adapted from [51].

During the four years of the Soy Moratorium (2007 to 2010) 2,973 thousand ha were deforested in the states of MT, PA and RO (Table 1), but deforestation rates are declining and in 2010 they reached the lowest level in a historic series of 22 years [5]. Although the results show that the land conversion from deforestation to soy is minor, the soy planted area is continuously increasing [52], particularly in MT. Recent works have shown that soy is mainly expanding on savanna and pasture land [53, 54]. Agriculture intensification through double cropping has also been observed in MT [42] which, coupled to the major effort of the Brazilian government to fight illegal deforestation, should reduce the pressure of expansion over native forest. 


\section{Conclusions}

The evaluation of the fourth year of monitoring new soy plantations within deforested polygons during the Soy Moratorium revealed to be minor with an area of 11,698 ha in crop year 2010/2011 in the states of Mato Grosso, Rondônia and Pará. These states are responsible for $99 \%$ of the soy planted within the Amazon biome and, considering its total deforested area during the Soy Moratorium (2007 to 2010 ), the 11,698 ha of soy corresponds to $0.39 \%$. Considering the deforestation of polygons $\geq 25$ ha in the 53 municipalities that altogether are responsible for $98 \%$ of the biome's soy planted area, this new soy area corresponds to $3.1 \%$.

It might be premature to conclude that the Soy Moratorium is actually having an inhibitory effect on recent deforestation in the Amazon biome but, from the figures, it is quite evident that the soy crop was not a significant deforestation driver during the Soy Moratorium.

Monitoring soy plantations in recently deforested polygons in the Amazon biome allowed the industries and exporters that participate in the Soy Moratorium to comply with their commitment not to acquire soy from areas that were deforested after July 24, 2006. The present work also demonstrates that remote sensing technology can significantly contribute to the governance process of Brazilian natural resources.

\section{Acknowledgments}

The authors wish to thank Magog Araújo, Flávia Mendes and Fernando Yuzo Sato, of INPE's Laboratory of Remote Sensing in Agriculture and Forestry (LAF) for the technical support that they provided.

\section{Conflict of Interest}

The authors declare no conflict of interest.

\section{References}

1. Mahar, D.J. Frontier Development Policy in Brazil: A Study of Amazonia; Praeger: New York, NY, USA, 1979; p. 182.

2. Pedlowski, M.A.; Dale, V.H.; Matricardi, E.A.T.; da Silva Filho, E.P. Patterns and impacts of deforestation in Rondônia, Brazil. Landscape Urban Plan. 1997, 38, 149-157.

3. Fearnside, P.M. Avança Brasil: Environmental and social consequences of Brazil's planned infrastructure in Amazonia. Environ. Manag. 2002, 30, 735-747.

4. Aguiar, A.P.D.; Câmara, G.; Escada, M.I.S. Spatial statistical analysis of land-use determinants in the Brazilian Amazonia: Exploring intra-regional heterogeneity. Ecol. Model. 2007, 209, 169-188.

5. Fearnside, P.M. Deforestation in Brazilian Amazonia: History, Rates, and Consequences; Blackwell Science Inc: Hoboken, NJ, USA, 2005; Volume 19, pp. 680-688.

6. Ros-Tonen, M. Novas perspectivas para a gestão sustentável da Floresta Amazônica: Explorando novos caminhos. Ambient. Soc. 2007, 10, 11-25. 
7. INPE. Monitoramento da Floresta Amazônica Brasileira por Satélite-Estimativas Anuais de desmatamento desde 1988 até 2009, 2011. Available online: http://www.obt.inpe.br/prodes/ prodes_1988_2010.htm (accessed on 15 September 2011).

8. Merry, F.; Soares, B.; Nepstad, D.; Amacher, G.; Rodrigues, H. Balancing conservation and economic sustainability: The future of the Amazon Timber industry. Environ. Manag. 2009, 44, 395-407.

9. Nepstad, D.; Stickler, C.; Almeida, O. Globalization of the Amazon soy and beef industries: Opportunities for conservation. Conserv. Biol. 2006, 20, 1595-1603.

10. Nepstad, D.C.; Stickler, C.M.; Soares, B.; Merry, F. Interactions among Amazon land use, forests and climate: Prospects for a near-term forest tipping point. Philos. Trans. R. Soc. B Biol. Sci. 2008, 363, 1737-1746.

11. Mertens, B.; Poccard-Chapuis, R.; Piketty, M.G.; Lacques, A.E.; Venturieri, A. Crossing spatial analyses and livestock economics to understand deforestation processes in the Brazilian Amazon: The case of São Félix do Xingú in South Pará. Agric. Econ. 2002, 27, 269-294.

12. McAlpine, C.A.; Etter, A.; Fearnside, P.M.; Seabrook, L.; Laurance, W.F. Increasing world consumption of beef as a driver of regional and global change: A call for policy action based on evidence from Queensland (Australia), Colombia and Brazil. Glob. Environ. Change Hum. Policy Dimens. 2009, 19, 21-33.

13. Faminow, M.D. Spatial economics of local demand for cattle products in Amazon development. Agric. Ecosyst. Environ. 1997, 62, 1-11.

14. Fearnside, P.M.; Laurance, W.F. Comment on "Determination of Deforestation Rates of the World's Humid Tropical Forests”. Science 2003, 299, doi:10.1126/science.1078714.

15. Laurance, W.F. Switch to corn promotes Amazon deforestation. Science 2007, 318, 1721.

16. Morton, D.C.; DeFries, R.S.; Shimabukuro, Y.E.; Anderson, L.O.; Arai, E.; Espirito-Santo, F.D.; Freitas, R.; Morisette, J. Cropland expansion changes deforestation dynamics in the southern Brazilian Amazon. Proc. Natl. Acad. Sci. USA 2006, 103, 14637-14641.

17. Elferink, E.V.; Nonhebel, S.; Uiterkamp, A. Does the Amazon suffer from BSE prevention? Agric. Ecosyst. Environ. 2007, 120, 467-469.

18. Fearnside, P.M. Soybean cultivation as a threat to the environment in Brazil. Environ. Conserv. 2001, 28, 23-38.

19. Brown, J.C.; Koeppe, M.; Coles, B.; Price, K.P. Soybean production and conversion of tropical forest in the Brazilian Amazon: The case of Vilhena, Rondonia. Ambio 2005, 34, 462-469.

20. GREENPEACE. Eating up the Amazon; Greenpeace International: Amsterdam, The Netherlands, 2006; p. 64.

21. Rudorff, B.F.T.; Adami, M.; Aguiar, D.A.; Moreira, M.A.; Mello, M.P.; Fabiani, L.; Amaral, D.F.; Pires, B.M. The soy moratorium in the Amazon Biome monitored by remote sensing images. Remote Sens. 2011, 3, 185-202.

22. Lovatelli, C. Cinco anos da Moratória da Soja e sustentabilidade do Bioma Amazônia. Polit. Externa 2011, 20, 125-137.

23. Brazilian Federal Government. Comitê Interministerial sobre Mudança do Clima; Plano Nacional sobre Mudança do Clima (PNMC): Brasília, Brazil, 2008; p. 154. 
24. Soares-Filho, B.S.; Nepstad, D.C.; Curran, L.M.; Cerqueira, G.C.; Garcia, R.A.; Ramos, C.A.; Voll, E.; McDonald, A.; Lefebvre, P.; Schlesinger, P. Modelling conservation in the Amazon basin. Nature 2006, 440, 520-523.

25. IBGE. Sistema IBGE de Recuperação Automática, 2011. Available online: http://www.sidra.ibge.gov.br/ (accessed on 13 October 2011).

26. Kintisch, E. Improved monitoring of rainforests helps pierce haze of deforestation. Science 2007, 316, 536-537.

27. Câmara, G.; Valeriano, D.d.M.; Soares, J.V. Metodologia para o Cálculo da Taxa Anual de Desmatamento na Amazônia Legal; INPE: São José dos Campos, Brazil, 2006; p. 24. Available online: http://www.obt.inpe.br/prodes/metodologia.pdf (accessed on 24 October 2011).

28. Shimabukuro, Y.E.; Batista, G.T.; Mello, E.M.K.; Moreira, J.C.; Duarte, V. Using shade fraction image segmentation to evaluate deforestation in Landsat Thematic Mapper images of the Amazon Region. Int. J. Remote Sens. 1998, 19, 535-541.

29. Anderson, L.O.; Shimabukuro, Y.E.; Defries, R.S.; Morton, D. Assessment of deforestation in near real time over the Brazilian Amazon using multitemporal fraction images derived from Terra MODIS. IEEE Geosci. Remote Sens. Lett. 2005, 2, 315-318.

30. Morton, D.C.; DeFries, R.S.; Shimabukuro, Y.E.; Anderson, L.O.; Del Bon Espírito-Santo, F.; Hansen, M.; Carroll, M. Rapid Assessment of annual deforestation in the Brazilian Amazon using MODIS data. Earth Interact. 2005, 9, 1-22.

31. Justice, C.O.; Vermote, E.; Townshend, J.R.G.; Defries, R.; Roy, D.P.; Hall, D.K.; Salomonson, V.V.; Privette, J.L.; Riggs, G.; Strahler, A.; et al. The Moderate Resolution Imaging Spectroradiometer (MODIS): Land remote sensing for global change research. IEEE Trans. Geosci. Remote Sens. 1998, 36, 1228-1249.

32. Alves, D.S. Space-time dynamics of deforestation in Brazilian Amazônia. Int. J. Remote Sens. 2002, 23, 2903-2908.

33. Asner, G.P. Cloud cover in Landsat observations of the Brazilian Amazon. Int. J. Remote Sens. 2001, 22, 3855-3862.

34. Sano, E.E.; Ferreira, L.G.; Asner, G.P.; Steinke, E.T. Spatial and temporal probabilities of obtaining cloud-free Landsat images over the Brazilian tropical savanna. Int. J. Remote Sens. 2007, 28, 2739-2752.

35. Wolfe, R.E.; Nishihama, M.; Fleig, A.J.; Kuyper, J.A.; Roy, D.P.; Storey, J.C.; Patt, F.S. Achieving sub-pixel geolocation accuracy in support of MODIS land science. Remote Sens. Environ. 2002, 83, 31-49.

36. Vermote, E.F.; El Saleous, N.Z.; Justice, C.O. Atmospheric correction of MODIS data in the visible to middle infrared: First results. Remote Sens. Environ. 2002, 83, 97-111.

37. Friedl, M.A.; McIver, D.K.; Hodges, J.C.F.; Zhang, X.Y.; Muchoney, D.; Strahler, A.H.; Woodcock, C.E.; Gopal, S.; Schneider, A.; Cooper, A.; et al. Global land cover mapping from MODIS: Algorithms and early results. Remote Sens. Environ. 2002, 83, 287-302.

38. Justice, C.O.; Townshend, J.R.G.; Vermote, E.F.; Masuoka, E.; Wolfe, R.E.; Saleous, N.; Roy, D.P.; Morisette, J.T. An overview of MODIS Land data processing and product status. Remote Sens. Environ. 2002, 83, 3-15. 
39. Huete, A.; Didan, K.; Miura, T.; Rodriguez, E.P.; Gao, X.; Ferreira, L.G. Overview of the radiometric and biophysical performance of the MODIS vegetation indices. Remote Sens. Environ. 2002, 83, 195-213.

40. Bernardes, T.; Adami, M.; Formaggio, A.R.; Moreira, M.A.; França, D.d.A.; Novaes, M.R.d. Imagens mono e multitemporais Modis para estimativa da área com soja no estado de Mato Grosso. Pesqui. Agropecu. Bras. 2011, 46, 1530-1537.

41. Epiphanio, R.D.V.; Formaggio, A.R.; Rudorff, B.F.T.; Maeda, E.E.; Luiz, A.J.B. Estimating soybean crop areas using spectral-temporal surfaces derived from MODIS images in Mato Grosso, Brazil. Pesqu. Agropec. Bras. 2010, 45, 72-80.

42. Galford, G.L.; Mustard, J.F.; Melillo, J.; Gendrin, A.; Cerri, C.C.; Cerri, C.E.P. Wavelet analysis of MODIS time series to detect expansion and intensification of row-crop agriculture in Brazil. Remote Sens. Environ. 2008, 112, 576-587.

43. EMBRAPA; INPE. TerraClass - Levantamento de informações de uso e cobertura da terra na Amazônia. Sumário Executivo. 2011; p. 20. Available online: http://www.inpe.br/cra/projetos_ pesquisas/sumario_executivo_terraclass_2008.pdf (accessed on 14 May 2012).

44. Rizzi, R.; Risso, J.; Epiphanio, R.D.V.; Rudorff, B.F.T.; Formaggio, A.R.; Shimabukuro, Y.E.; Fernandes, S.L. Estimativa da área de soja no Mato Grosso por meio de imagens MODIS. In Proceedings of the INPE Anais XIV Simpósio Brasileiro de Sensoriamento Remoto, Natal, Brazil, 25-30 April 2009; pp. 387-394.

45. Huete, A.R.; Liu, H.Q.; Batchily, K.; van Leeuwen, W. A comparison of vegetation indices over a global set of TM images for EOS-MODIS. Remote Sens. Environ. 1997, 59, 440-451.

46. Arvor, D.; Jonathan, M.; Meirelles, M.S.P.; Dubreuil, V.; Durieux, L. Classification of MODIS EVI time series for crop mapping in the state of Mato Grosso, Brazil. Int. J. Remote Sens. 2011, 32, 7847-7871.

47. Adami, M.; Rudorff, B.F.T.; Freitas, R.M.; Aguiar, D.A.; Sugawara, L.M.; Mello, M.P. Remote sensing time series to evaluate direct land use change of recent expanded sugarcane crop in Brazil. Sustainability 2012, 4, 574-585.

48. Divisão de Geração de Imagens. Image Catalogue. Available online: http://www.dgi.inpe.br/ siteDgi_EN/index_EN.php (accessed on 10 October 2010).

49. ABIOVE. Monitoring of the Soy Moratorium 2010/11. Available online: http://www.abiove.com.br/english/ss_relatoriouso10_us.asp (accessed on 15 January 2012).

50. Sorrensen, C. Contributions of fire use study to land use/cover change frameworks: Understanding landscape change in agricultural frontiers. Hum. Ecol. 2004, 32, 395-420.

51. CONAB. Acompanhamento de Safra Brasileira de Grãos-Décimo Primeiro Levantamento; CONAB: Brasília, Brazil, 2011; p. 41.

52. CONAB. Séries históricas relativas às safras 1976/77 a 2009/2010 de área plantada, produtividade e produção, 2011. Available online: http://www.conab.gov.br/conteudos.php $? \mathrm{a}=1252 \& \mathrm{t}=($ accessed on 12 November 2011$)$.

53. Arvor, D.; Meirelles, M.; Dubreuil, V.; Bégué, A.; Shimabukuro, Y.E. Analyzing the agricultural transition in mato grosso, brazil, using satellite-derived indices. Appl. Geogr. 2012, 32, 702-713. 
54. Macedo, M.N.; DeFries, R.S.; Morton, D.C.; Stickler, C.M.; Galford, G.L.; Shimabukuro, Y.E. Decoupling of deforestation and soy production in the southern amazon during the late 2000s. Proc. Natl. Acad. Sci. USA 2012, 109, 1341-1346.

(C) 2012 by the authors; licensee MDPI, Basel, Switzerland. This article is an open access article distributed under the terms and conditions of the Creative Commons Attribution license (http://creativecommons.org/licenses/by/3.0/). 